Jurnal Lensa Mutiara Komunikasi Vol. 5, No. 1 (Juni 2021) 30-41

ISSN 2579-8332 (Online) | http://u.lipi.go.id/1487661056

\title{
Pola Komunikasi Wartawan Istana dalam Membuat Berita
}

\author{
Erik Purnama Putra \\ Program Studi Komunikasi Politik, Universitas Paramadina \\ Jl. Gatot Subroto No. kav. 97, Kec. Mampang Prpt, Kota Jakarta Selatan \\ E-mail: erik.putra@ students.paramadina.ac.id
}

Received: Januari 2021; Accepted: April 2021; Published: Juni 2021

\begin{abstract}
This research is aimed to describe the communication patterns of the Presidential Palace journalists when they want to get and write news. The journalists who were assigned in Predidential Palace must come from different media. There were dozens of journalists from various media who were assigned in the Presidential Palace. However, the Presidential Palace journalists had been seen as prestigious because they were assigned in important posts. This research used a constructivist paradigm approach. The dats collection was carried out by observing and interviewing the journalists in the field. In writing news, the Presidential Palace journalists were also bounded by the agreement between the journalists from various media who are assigned to the Presidential Palace. The results showed that Presidential Palace journalists shared news with each other and established communication, so that everyone could get news. Among the Presidential Palace journalists, sharing the results of interviews was common. This condition made the news that appeared in various media, especially online, to be almost the same, even though the angle chosen is different. They also did not know the practice of breaking into or looking for exclusive news, because if that happened, the access to information could be closed.
\end{abstract}

Keywords: Presidential Palace journalists; journalists sharing transcripts; online media.

\begin{abstract}
Abstrak
Penelitian ini berupaya menggambarkan pola komunikasi wartawan Istana Kepresidenan ketika ingin mendapatkan dan membuat berita. Wartawan yang bertugas di Istana tentu saja berasal dari berbagai media yang berbeda. Ada puluhan wartawan berbagai media yang ditugaskan di Istana. Hanya saja, wartawan Istana selama ini, dipandang memiliki gengsi tersendiri lantaran menempati pos penting. Penelitian ini menggunakan pendekatan paradigma konstruktivis. Pengumpulan data dilakukan dengan mengobservasi dan mewawancarai wartawan di lapangan. Dalam membuat berita, wartawan Istana tidak hanya mengandalkan agenda presiden, wawancara, maupun menunggu press release yang disediakan Biro Pers semata. Mereka juga bisa berinisiatif membuat janji wawancara dengan pejabat di lingkungan Istana Kepresidenan. Hanya saja, terkesan berita yang muncul, khususnya di media daring memiliki angle atau isi yang hampir sama. Hal itu terjadi lantaran praktik berbagi transkrip di kalangan wartawan sudah biasa dilakukan. Ternyata, dalam membuat berita, wartawan terikat dengan kesepakatan antarwartawan dari berbagai media yang bertugas di Istana. Hasil penelitian menunjukkan wartawan Istana dalam membuat berita saling berbagi satu sama lain, dan menjalin komunikasi agar semuanya bisa mendapatkan berita. Di kalangan wartawan Istana, berbagi hasil wawancara merupakan hal biasa. Kondisi itu membuat berita yang muncul di berbagai media, khususnya daring menjadi hampir serupa, meski angle yang dipilih berbeda. Mereka juga tidak mengenal praktik bobol atau mencari berita eksklusif, karena jika hal itu terjadi maka akses informasi bisa ditutup.
\end{abstract}

Kata kunci: wartawan Istana; wartawan berbagi transkrip; media daring; Istana Kepresidenan.

doi: https://doi.org/10.51544/jlmk.v5i1.1634

(C) 2021 Jurnal Lensa Mutiara Komunikasi. This is an open access article under the CC BY-SA license Website: http://e-journal.sari-mutiara.ac.id/index.php/JLMI/

http://e-journal.sari-mutiara.ac.id 


\section{PENDAHULUAN}

Wartawan adalah salah satu profesi yang memiliki privilage. Bentuk hak istimewa atau keunggulan yang didapatkan wartawan, di antaranya bisa masuk ke berbagai instansi dan lembaga pemerintahan. Mereka juga bisa bertemu dengan mudah narasumber dari kalangan pejabat pemerintah atau figur terkenal.

Wartawan adalah orang yang bekerja di media, baik itu cetak, elektronik, dan radio. Dalam Pasal 1 Undang-Undang (UU) Nomor 40 Tahun 1999 tentang Pers, dijelaskan bahwa wartawan adalah orang yang secara teratur melaksanakan kegiatan jurnalistik. Wartawan dalam melaksanakan kegiatan jurnalistik bertugas mencari, memperoleh, memiliki, menyimpan, mengolah, dan menyampaikan informasi, baik dalam bentuk tulisan, suara, gambar, suara dan gambar, serta data dan grafik, maupun dalam bentuk lainnya.

Wartawan atau jurnalis adalah seorang yang melakukan aktivitas jurnalisme atau memproduksi berupa laporan dan tulisannya dikirimkan atau dimuat di media massa secara teratur untuk disampaikan kepada masyarakat (Fitri Melia Sari, 2014).

Di kalangan wartawan yang bekerja di Jakarta, semua kantor kementerian, instansi atau lembaga pemerintah, serta pejabat daerah bisa dengan mudah didatangi. Hanya ada satu tempat yang tidak bisa dengan mudah diakses wartawan, yaitu Istana Kepresidenan. Selain pengamanan yang ketat, hanya wartawan yang terdaftar pula yang boleh masuk. Selain itu, wartawan juga harus memakai baju rapi atau formal, dengan celana jin tidak dibolehkan masuk.

Pada era Presiden Joko Widodo (Jokowi), setiap media pers punya kesempatan menugaskan jurnalis di Istana dengan tetap mengikuti persyaratan yang sudah ditetapkan dan telah terdaftar secara resmi di Biro Pers, Media, dan Informasi Sekretariat Presiden. Menurut Roswita Oktavianti (2016), ada aturan wartawan yang ditugaskan di Istana minimal memiliki pengalaman dua tahun.

Jika di tempat lain wartawan bisa dengan mudah keluar masuk dan bergantian dengan rekan untuk meliput, tidak halnya yang terjadi di Istana Kepresidenan. Di sini, setiap wartawan harus memiliki kartu pers (ID press) khusus yang dikeluarkan Biro Pers dan Informasi yang berada di bawah Kementerian Sekretariat Negara (Kemensetneg), untuk bisa meliput aktivitas presiden maupun wakil presiden setiap harinya.

Bagi wartawan yang ingin mendapatkan kartu pers khusus Istana harus mendaftar dulu setiap tahunnya, yang biasanya dilakukan sebelum pergantian tahun. Itu pun yang bisa mendaftar adalah wartawan yang bekerja di media yang tersertifikasi Dewan Pers. Sehingga tidak semua media bisa menempatkan wartawan di Istana.

Alhasil, ada anggapan jika wartawan yang ditugaskan di Istana dikenal sebagai mereka yang terpilih. Hanya sedikit jurnalis yang mendapat kesempatan menjadi wartawan Istana. Selain harus melewati proses seleksi dan birokrasi yang ditentuk Kemensetneg, wartawan juga harus ditunjuk oleh kantor tempatnya bekerja.

Meski begitu, tugas wartawan Istana tetap sama dengan wartawan lainnya, yaitu melakukan peliputan atau aktivitas jurnalistik. Setiap hari mereka diwajibkan untuk mengirim berita ke kantor. Semua aktivitas di Istana wajib diliput tanpa terkecuali. Pun dengan pemberitaan harus dilakukan secara objektif.

Tentu saja menjadi wartawan Istana memiliki tantangan tersendiri. Hal itu lantaran agenda presiden yang padat harus terus dipantau dan dijadikan berita. Sehingga wartawan harus bekerja tidak kenal waktu mengikuti agenda presiden untuk memberitakan serangkaian agenda tanpa mengenal libur dan jam kerja. 
Dalam membuat berita, wartawan Istana tidak melulu harus menjadi kepanjangan tangan pihak Istana. Mereka bisa saja membuat berita berisi kritikan kepada presiden dan jajarannya. Semua berita itu sesuai dengan perintah dari kantor masing-masing wartawan. Di sini, tingkat kredibilitas suatu media ada kaitannya dengan kualitas para awak wartawan di lapangan (Wibawa, 2012).

Di sini jelas, wartawan dituntut untuk kreatif dalam membuat berita. Hal itu lantaran wartawan yang bertugas di Istana berjumlah puluhan orang. Mereka harus saling bersaing satu sama lain membuat berita untuk dikirim ke kantor masing-masing. Sehingga setiap wartawan wajib mendapatkan komentar menarik atau bagus dari sang narasumber yang diwawancarai. Sudah menjadi kewajiban pula bagi setiap wartawan Istana untuk ke lapangan.

Sayangnya, hasil berita yang muncul dari berbagai media, khususnya daring terkesan memiliki angle yang sama. Hal itu terjadi lantaran biasanya para wartawan saling berkoordinasi dan berkomunikasi satu sama lain. Ketika hendak membuat berita, mereka biasanya saling berbagi materi wawancara. Komunikasi wartawan satu dan lainnya yang ngepos di Istana menjadi sebuah kebiasaan sehari-hari. Komunikasi merupakan peranan penting dalam melakukan berbagai aktivitas, termasuk pekerjaan (S. N. Sari and Marajari 2016).

Dalam jurnalistik, pembuatan berita yang memiliki lead dan sudut pandang yang mirip dianggap sebagai bentuk kloning. Praktik kloning tidak melulu tukar-menukar berita atau hasil wawancara. Menurut (Garini and Besman 2018), ketika wartawan menggunakan hasil liputan orang lain dan membuat berita seolah-olah sumber berita tersebut merupakan hasil dari liputannya sendiri juga masuk kategori tersebut.

Roswita Oktavianti (2018), menjelaskan, kehadiran jurnalis media daring yang mengejar kuantitas dan kecepatan berita menjadi faktor pemicunya. Semakin banyaknya berita singkat dari hasil wawancara doorstop dan dibagi ke temannya membuat isi berita menjadi hampir seragam. Padahal, mereka berasal dari berbagai media, yang seharusnya membuat berita dengan isi yang berbeda.

Mengapa hal itu bisa terjadi? Mengapa mereka tidak membuat berita sendiri-sendiri? Latar belakang seperti itulah yang mendorong peneliti untuk mengkaji 'Pola Komunikasi Wartawan Istana dalam Mendapatkan Berita'. Penelitian ini mencoba menggali pola kerja informan selama menjadi wartawan Istana. Apakah dalam kesehariannya, mereka tetap menjaga profesionalitas dalam mendapatkan berita atau mengesampingkan etika jurnalistik.

Penelitian ini menjadi menarik, karena belum ada penelitian sebelumnya yang secara khusus meneliti pola komunikasi wartawan Istana dalam usahanya untuk mendapatkan berita yang diinginkan kantor atau atas inisiatif sendiri. Peneliti membatasi informan yang digunakan adalah wartawan yang bertugas di media online atau daring dan cetak atau koran.

\section{METODE PENELITAN}

Penelitian ini menggunakan pendekatan kualitatif. Fokus utama penelitian kualitatif adalah memahami perilaku, persepsi, dan pengalaman. Studi dilakukan terhadap wartawan yang bertugas di Istana Kepresidenan.

Penelitian ini ini menggunakan paradigma konstruktivis dan meneliti bagaimana realitas wartawan Istana dalam bekerja sehari-hari. Penelitian kualitatif adalah penelitian yang digunakan untuk meneliti kondisi objek alamiah, di mana peneliti merupakan instrumen kunci (Sugiyono 2017).

Iman Gunawan (2013) menjelaskan bahwa metode kualitatif berusaha memahami dan menafsirkan makna suatu peristiwa interaksi tingkah laku manusia dalam situasi tertentu 
menurut perspektif peneliti sendiri. Penelitian yang menggunakan penelitian kualitatif bertujuan untuk memahami objek yang diteliti secara mendalam

Penelitian kualitatif bertujuan untuk mendapatkan pemahaman yang sifatnya umum terhadap kenyataan sosial dari perspektif partisipan (Pupu Saeful Rahmat, 2009). Pendekatan kualitatif diharapkan mampu menghasilkan uraian yang mendalam tentang ucapan, tulisan, dan atau perilaku yang dapat diaman dari suatu individu.

Di sini, peneliti yang menggunakan tiga informan ingin memahami objek yang diteliti secara mendalam, yaitu sebuah prosedur penelitian yang menghasilkan data deskriptif berupa kata tertulis atau lisan (verbatim) dari subjek yang diamati.

Alasan memilih tiga informan tersebut lantaran mereka sudah ditempatkan di Istana Kepresidenan lebih empat tahun. Pun ketiga wartawan tersebut mewakili media cetak dan online, media online, dan media cetak. Maksudnya, ketiganya informan dalam membuat berita, yang satu menyuplai untuk koran dan website, untuk website saja, dan terakhir untuk koran saja.

Di sini, penelitian kualitatif bertujuan untuk menjelaskan suatu fenomena sedalamdalamnya dengan cara pengumpulan data yang sedalam-dalamnya pula, yang menunjukkan pentingnya kedalaman dan detail suatu data yang diteliti. Sehingga analisis di sini digunakan untuk mengetahui pola komunikasi wartawan Istana dalam bekerja mencari berita.

\section{HASIL DAN PEMBAHASAN}

Dalam membuat berita, wartawan Istana biasanya mendapat pasokan materi dari beberapa cara. Bisa mengutip pidato presiden, bertanya di acara konferensi pers, wawancara spontan (door stop), atau bersumber dari press release yang dikirim Biro Pers. Dari beragam sumber tersebut, setiap wartawan harus mengolahkan untuk dikirimkan ke kantornya masingmasing.

Hanya saja, memang era sekarang membuat wartawan dituntut untuk membuat berita cepat. Apa yang terjadi di lingkaran Istana, harus segera diberitakan. Alhasil, setiap wartawan harus langsung mengetik materi yang sudah didapat untuk segera diberitakan.

Dalam mencari berita, wartawan selalu berusaha memenuhi tugas yang diberikan kantor, yang dalam hal ini biasanya dilakukan oleh redaktur atau koordinator lapangan. Wartawan Istana juga memiliki tanggung jawab yang sama dengan wartawan lainnya. Hanya saja, mereka seharihari lebih banyak berinteraksi dengan pejabat tinggi negara. Mulai presiden, wakil presiden, menteri, pejabat sipil dan militer, serta tamu yang biasa datang ke Istana Kepresidenan, yang tentu biasanya figur penting atau terkenal.

Untuk itu, wartawan dituntut untuk memiliki kemampuan berkomunikasi yang baik supaya bisa menjaga hubungan dengan narasumber. Karena bagaimana pun juga, Istana selama ini memang menjadi salah satu pos yang menjadi pusat pemberitaan. Hampir semua agenda atau aktivitas di lingkungan Istana bisa diberitakan.

Karena jika ada pejabat mengambil kebijakan atau keputusan, dampaknya pasti berpengaruh ke seluruh rakyat Indonesia. Sehingga wartawan juga dituntut untuk lebih meningkatkan kemampuan dalam membuat berita agar tidak terjebak dalam rutinitas sehari-hari. Pun dengan angle berita yang dibuat tidak monoton dan hampir serupa dengan media lain, sehingga gaya penyajian tulisan tetap enak dibaca.

Atau ada cara lain bagi wartawan mendapatkan berita tidak biasa, yaitu dengan melakukan wawancara eksklusif ke pejabat terkait. Karena konteksnya di sini wartawan bekerja untuk media cetak atau daring, biasanya siapa yang lebih dulu mendapatkan berita itu yang dianggap memiliki jaringan lebih baik. Jaringan yang dimaksud tentu saja terkait daya tembus ke 
narasumber dan mengendus informasi di balik layar, untuk kemudian dikonfirmasi kepada pejabat berwenang.

Tujuan dari itu semua memang agar terbentuk wartawan profesional yang bisa menghasilkan berita berkualitas, yang produknya dapat dikonsumsi masyarakat luas. Tidak hanya itu, berita yang dibuat wartawan juga dapat menjadi pertimbangan atau masukan bagi pemangku kepentingan dalam membuat kebijakan di lingkungan Istana.

Dalam mencari dan membuat berita, wartawan Istana atau bertugas di Istana biasanya tentu saja memprioritaskan perintah yang datang dari kantor. Mereka dalam membuat berita pasti mengutamakan menyelesaikan tugas dari kantor. Hal itu lantaran mereka bertugas di Istana juga berkat ditunjuk oleh kantor media masing-masing. Sehingga jika tugas dari kantor tidak dikerjakan, tentu ada konsekuensi yang harus diterima.

Dalam proses ini, kadang wartawan kesulitan untuk mendapatkan konfirmasi atau wawancara dari narasumber. Apalagi jika pejabat tersebut sulit ditemui secara langsung. Akhirnya, ada wartawan yang memilih untuk meminta materi atau ada yang secara sukarela membagikan materi wawancara yang didapat kepada rekannya dari media lain.

Di sini tercipta saling komunikasi antarwatawan. Komunikasi antarpribadi bisa berlangsung dengan menggunakan alat bantu atau media seperti, telepon, surat, telegram, aplikasi, dan sebagainya. Komunikasi antarpribadi dikatakan efektif dalam merubah perilaku orang lain apabila kesamaan makna mengenai apa yang dibincangkan (Simamora dan Sihombing, 2017).

Teknologi yang semakin maju sangat memudahkan wartawan Istana untuk mendapatkan berita. Mereka lebih memilih pola kerja sama dengan wartawan lain daripada bersaing satu sama lain demi mendapatkan berita eksklusif. Dengan saling bekerja sama, maka setiap wartawan Istana bisa mendapatkan berita yang diinginkan. Hal itu tentu saja mereka bisa tenang lantaran tugas dari kantor bisa ditunaikan.

Adapun pola komunikasi yang dilakukan wartawan Istana dalam membuat berita biasanya lebih banyak wawancara pejabat yang memiliki agenda menemui presiden. Jika sepi agenda, wartawan Istana berinisiatif membuat janji wawancara narasumber secara ramai-ramai agar tetap mendapatkan berita pada hari itu. Bisa juga wartawan mewawancarai pejabat dengan menelepon atau mengirim pesan.

Satu lagi aktivitas yang menjadi ciri wartawan Istana adalah berbagi transkrip hasil wawancara dengan narasumber. Mengutip pendapat Garini and Besman (2018), pantulan transkrip wawancara, foto, dan berita seringkali digunakan sebagai sumber berita ketika wartawan yang bersangkutan sedang tidak berada di lokasi kejadian.

Biasanya, bagi-bagi transkrip dilakukan antarwartawan ketika ada agenda rapat kabinet yang dihadiri presiden, wakil presiden, seluruh menteri, dan pejabat setingkat menteri. Karena ketika selesai mereka semua keluar berbarengan, biasanya wartawan Istana akan memprioritaskan mewawancarai menteri yang sedang ramai dibicarakan publik atau mewawancarai pejabat yang disesuaikan dengan tugas dari kantor.

Tentu saja, di sini setiap wartawan dituntut untuk pandai berkomunikasi satu sama lain. Karena jika tidak pandai menjaga komunikasi, seorang wartawan bisa ketinggalan informasi dan imbasnya bisa tidak mendapatkan berita sama sekali, karena informasi tidak sampai kepadanya. Griffin (2011) mengatakan, komunikasi adalah proses relasional untuk membuat dan menafsirkan pesan yang mendapatkan tanggapan.

Sama seperti wartawan pada umumnya, wartawan Istana juga dalam membuat berita biasanya melakukan listing atau melaporkan isu yang menarik untuk diliput kepada redaktur atau 
koordinator liputan (korlip) di kantor, sebelum berangkat ke pos liputan. Bisa juga jika memang kondisi sedang landai, wartawan Istana masih bingung dengan berita apa yang layak atau menarik untuk diangkat dan dibuat.

Ahmad Fikri Ali (2016) mengatakan, ada dua cara wartawan dalam membuat berita. Pertama, meliput peristiwa dengan mendatangi secara teratur instansi pemerintah atau swasta, atau tempat yang dimungkinkan munculnya peristiwa, informasi untuk dijadikan berita. Kedua, aktif mencari bahan berita dengan menindak lanjuti informasi yang didapat.

Sumber wartawan bisa dari lapangan, internet, kantor berita, hingga siaran pers. Wartawan adalah pencari fakta. Fakta yang dilengkapi dengan benar akan sama dengan kebenaran itu sendiri. Karena itu, wartawan setiap membuat berita selalu harus melakukan konfirmasi terlebih dahulu kepada narasumber terkait atau berkompeten. Baru setelah itu bisa menuliskannya agar bisa menjadi berita yang dapat dipertanggungjawabkan isinya.

Jika memang ada isu yang menarik, pasti tugas dari kantor sudah diberikan pada malam hari, sebelum keesokan harinya mereka berangkat ke Istana. Dari situ, mereka wajib untuk membuat berita sesuai dengan permintaan kantor media masing-masing. Karena Istana Kepresidenan adalah pos penting yang merupakan sumber atau gudang berita, maka setiap hari ada saja berita yang bisa dibuat oleh wartawan.

Dalam konteks wartawan daring dan cetak (biasanya tetap juga mengirim untuk dipakai versi online), mereka yang sudah terlatih mengetik cepat, tidak perlu menunda waktu lagi untuk membuat berita seusai wawancara selesai. Sehingga dalam hitungan menit, usai wawancara menteri, misalnya, berita dari Istana Kepresidenan sudah dikirim ke kantor. Dan, redaktur piket langsung menaikkan berita tersebut ke website atau laman untuk bisa dinikmati pembaca.

Selama proses membuat berita, biasanya jika nilai berita itu sangat tinggi atau penting, wartawan Istana bisa langsung mengontak redaktur yang piket. Hal itu agar berita yang dikirim ke email yang tersambung ke kantong berita milik media masing-masing, bisa langsung diambil atau ditandai redaktur piket supaya lekas naik di laman daring.

Sedangkan jika memang berita yang dibuat memang biasa saja dan bukan peristiwa, wartawan Istana juga merasa tidak masalah berita itu naik di laman dalam waktu beberapa jam kemudian, atau malah memang dipakai di koran. Seperti yang disampikan (McLuhan 2020), media daring memiliki kekuatan yang tidak dimiliki oleh media cetak dan media elektronik. Tentu saja di sini yang dimaksud adalah kecepatan.

Menurut Yohanes Widodo (2017), mengatakan, kehadiran jurnalisme daring telah merevolusi pemberitaan, di mana kecepatan menjadi faktor utama. Kini, berita bukan lagi peristiwa yang 'telah berlangsung', tetapi peristiwa yang 'sedang berlangsung' yang disiarkan media.

Christiany Juditha (2016) menjelaskan, sifat dan karakteristik berita yang dimuat di media daring yang cenderung singkat dan cepat agar bisa sesegera mungkin diketahui oleh masyarakat luas. Hal yang sama terjadi di lingkungan Istana, di mana wartawan biasanya lekas menulis berita ketika ada suatu acara atau peristiwa penting.

Karena bagaimana pun, wartawan koran pun sekarang memiliki versi daring sehingga ada kebijakan dari kantornya untuk mengirim berita secepatnya. Dalam kasus presiden atau menteri mengadakan konferensi pers, wartawan kadang tidak menunggu sampai acara selesai.

Mereka menaruh rekaman atau menulis cepat pernyataan narasumber. Setelah dirasa mendapatkan kalimat yang menarik untuk dijadikan berita, wartawan langsung menulisnya. Setelah jadi, langsung dikirim. Dalam hitungan waktu tidak terlampau lama, berita sudah muncul di laman media bersangkutan. 
Pun dengan momen ketika presiden melantik menteri atau pejabat tinggi, wartawan Istana dalam membuat berita juga seperti dikejar waktu. Malahan, mereka bisa membuat berita preview terkait agenda pelantikan. Sebelum ketika acara dimulai, mereka baru memberitakan acara pelantikan itu sendiri. Jika dalam situasi seperti itu, biasanya semua wartawan Istana hadir meliput.

Secara garis besar, alur kerja wartawan Istana adalah setiap hari mengikuti agenda presiden atau pejabat terkait. Kemudian membuat berita dengan mengetiknya usai wawancara atau merekam pidato, mengirim berita ke kantor lewat gawai (gadget), dipilah redaktur apakah layak untuk naik atau tidak, diedit redaktur, tayang di laman (website) bagi media daring atau koran bagi media cetak.

Jika sedang tidak ada agenda internal di Istana, wartawan akan terus berusaha mencari informasi di balik layar untuk tetap mendapatkan berita. Pastinya, mereka tetap harus mengirim berita ke kantor sebagai absen agar dihitung masuk kerja. Pun wartawan juga bisa berinisiatif menghubungi narasumber atau membuat janji bertemu di kantornya untuk wawancara ramairamai.

Hanya saja, kadang wartawan Istana saling berbagi berita atau cukup membantu rekannya dengan menanyakan titipan pertanyaan kepada sang narasumber. Langkah kerja sama itu dilakukan demi menjaga hubungan baik antarwartawan sekaligus saling tolong-menolong. Konsekuensi dari semua itu memang kadang berita yang muncul di berbagai media menjadi seragam.

Tabel 1

Daftar informan atau narasumber

\begin{tabular}{|c|c|c|}
\hline Nama & Nama Media & Jenis Media \\
\hline Agus & Viva.co & Daring \\
\hline Doli & Koran Jakarta & Cetak \\
\hline Desi & Republika & Cetak dan Daring \\
\hline
\end{tabular}

Desi sebagai wartawan Istana sejak tiga tahun lalu dari Harian Republika dan Republika Online, menjelaskan bahwa:

"Kalau ada order kantor atau isu kantor, ya diprioritaskan. Sisanya paling kita titip tanyakan teman. Tolong tanyakan isu ini ya. Banyak yang titip ke teman karena agenda presiden kadang tidak bisa ditebak. Kadang ada agenda dadakan pagi, saya baru sampai Istana pukul 09.00 WIB, mau tidak mau ya titip duluan ke teman yang sudah ada di pressroom."

Fadholi selaku wartawan Koran Jakarta, yang mendapat pos liputan di Istana sejak 2015, mengatakan bahwa:

"Kalau di Istana memang mencari berita sumbernya terbatas, bisa pidato presiden, konferensi pers, wawancara dadakan, atau press release. Karena sekarang masa pandemi, banyak acara dilakukan secara virtual. Jika ada order khusus dari kantor, tentu menghubungi pejabat yang dituju. Jika sudah mentok, ya larinya ke juru bicara (presiden)."

Agus sebagai wartawan Viva.co.id, yang ditugaskan di Istana Kepresidenan sejak 2016, menjelaskan bahwa:

"Pola komunikasi wartawan memang mendahulukan tugas dari kantor. Biasanya kalau sedang sepi berita, saya janjian lewat Whatsapp dengan Sekretaris Kabinet (Pramono Anung). Tapi kalau itu ada waktu dan dia berkenan. Di Istana, sistemnya tidak bisa wawancara sendiri, tapi ramai-ramai. Kalau dalam isu atau kasus tertentu kadang di Istana memang sulit mendapatkan berita. Kalau saya tinggal memberi penjelasan ke kantor bahwa narasumber 
tersebut belum ada jawaban atau kalau doorstop tidak mau (berkomentar), saya tulis 'memilih menghindar'. Begitu saja sih.”

Di sini, setiap wartawan Istana memang dituntut oleh kantor masing-masing untuk tetap berusaha mendapatkan berita sesuai permintaan kantor sampai benar-benar menemui jalan buntu. Jika kondisinya seperti itu, mereka biasanya membuat janji bareng-bareng untuk menemui salah satu pejabat Istana agar berkenan memberi pernyataan dalam menanggapi isu yang menjadi pembicaraan atau mendapat sorotan publik.

Hanya saja, informan sepakat jika memang praktik berbagi transkrip marak terjadi. Bahkan ada grup khusus bagi wartawan untuk berbagi hasil wawancara dengan narasumber. Semua itu dilakukan karena mereka membuat perjanjian tidak tertulis di kalangan para wartawan Istana agar jangan sampai ada praktik seseorang membuat berita eksklusif.

Ketiga informan juga mengatakan, belakangan ini kerap pejabat di lingkungan Istana sulit ditemui atau berkenan memberikan statemen untuk mengklarifikasi masalah yang mendapat sorotan publik. Misalnya dalam kasus pengesahan Undang-Undang (UU) Cipta Kerja, yang semua pejabat memilih diam tidak memberikan pernyataan. Hal itu jelas membuat jengkel wartawan Istana, karena tidak mendapatkan berita sama sekali. Apalagi, mereka juga terus ditagih kantor untuk meminta komentar dari pejabat Istana.

Informan lainnya bercerita, ia berupaya terus melobi pejabat dengan mengajak rekannya yang memiliki kedekatan pribadi dengan narasumber agar mau diwawancarai. Semua cara dilakukan wartawan Istana demi mendapatkan berita supaya tugas dari kantor dapat diselesaikan. Jika memang sudah menemukan jalan buntu, ia dengan berat hati meminta maaf ke redaktur atau atasan karena, baik pesan singkat, telepon, maupun Whatsapp yang dikirim diabaikan narasumber.

Meski begitu, jika wartawan orderan dari kantor tidak bisa dipenuhi, mereka tidak sampai berkecil hati karena yang dialaminya juga dirasakan wartawan Istana lain. Karena di kalangan mereka sudah sepakat untuk saling tidak membuat berita sendiri untuk kantornya dengan alasan tidak boleh ada rekannya yang kebobolan.

Setiap wartawan Istana wajib memiliki rasa solidaritas kepada wartawan lain supaya bisa tetap menjaga hubungan baik dalam mendapatkan berita. Salah satu praktik yang umum dilakukan adalah berbagi transkrip usai wawancara dengan narasumber. Dari transkrip itulah, wartawan lain yang kebetulan sedang berhalangan atau masih dalam perjalanan, atau ada tugas dari kantor ke tempat lain, tetap tidak ketinggalan untuk membuat berita.

Sehingga menjadi hal lumrah di kalangan wartawan Istana untuk berbagi hasil wawancara narasumber, yang konsekuensinya memang membuat angle pemberitaan menjadi mirip. Meski misalnya ada puluhan wartawan, khususnya media cetak dan daring yang bertugas di Istana, namun karena sumber wawancara dari pejabat yang sama, dan seorang wartawan membagikan transkrip tersebut di grup maka sudah menjadi kesepakatan bersama.

Dari ketiga informan, mereka sepakat jika praktik berbagi transkrip atau hasil wawancara merupakan hal biasa. Biasanya materi wawancara untuk dijadikan berita dibagikan di grup Whatsapp. Sehingga setelah materi dibagikan, para wartawan Istana, khusunya yang medianya memiliki versi daring langsung mengolahnya untuk menjadi berita.

Di sini, siapa saja bisa membagikan materi wawancara, atau antarwartawan saling berbagi karena mereka sepakat untuk meringakan tugas masing-masing. Misalnya, ada wawancara beberapa menteri maka satu wartawan menjadikan materi wawancara untuk ditranskrip dan dibagikan ke rekan lainnya. Dengan saling berbagi seperti itu maka beban tugas menjadi lebih ringan. 
Kesepakatan di sini adalah seluruh wartawan Istana dibolehkan mengutip atau menjadikannya sebagai bahan berita untuk media masing-masing. Hanya saja, (Sirikit Syah, 2011) dalam Rambu-Rambu Jurnalistik menganggap pola komunikasi wartawan Istana dalam mencari berita itu termasuk praktik jurnalisme kloning. Biasanya yang paling sering melakukan itu adalah wartawan media daring, yang cenderung memang dituntut kecepatan dalam membuat berita.

Meski demikian, di kalangan wartawan Istana menganggap berbagi transkrip merupakan hal biasa, dan malah tidak bisa dihindari. Hal itu lantaran di antara wartawan Istana ada kesepakatan bersama bahwa meski mereka berasal dari perusahaan berbeda, namun di lapangan mereka memiliki tujuan yang sama. Ketiga informan yang diwawancara peneliti membenarkan, sulit bagi seorang wartawan untuk mendapatkan berita eksklusif di Istana.

Hidayat dan Anisti (2015) menjelaskan, tren kloning berita bisa saja dilakukan secara sadar maupun tidak disadari, seiring hadirnya media daring, sehingga mempermudah insan pers untuk menangkap isu berita. Penjelasan itu memang sesuai dengan kenyataan di lapangan, di mana informan menganggap berbagi transkrip bukan sebuah hal yang salah, karena lumrah dilakukan sejak wartawan Istana era sebelumnya.

Dengan kerja sama model itu, praktik bobol atau mendapatkan berita sendiri, sementara media lain tidak tahu, cenderung bisa membuat seorang wartawan itu bisa dimusuhi oleh wartawan Istana lainnya. Apalagi jika itu dilakukan wartawan baru mencoba membuat berita sendiri yang bersifat eksklusif yang isunya menarik, meski merupakan perintah dari kantornya, konsekuensi yang diterima wartawan Istana tersebut bisa berat lantaran telah melanggar 'etika bersama'.

Informan menjelaskan, jika ada kasus seperti itu biasanya sang wartawan itu akan dicecar secara ramai-ramai oleh wartawan Istana lainnya, dan tidak boleh masuk milis, yang kerap memuat informasi penting. Satu hal lagi, seluruh akses akan ditutup, sehingga wartawan itu bisa terkucilkan dengan sendirinya. Sehingga di sini, memang terbentuk solidaritas antarwartawan dalam membuat berita, yang itu harus disepakati bersama bagi mereka yang ditugaskan kantor media untuk ngepos di Istana.

Dengan situasi seperti itu, tentu seorang wartawan harus berpikir berkali-kali jika ingin membuat berita eksklusif untuk kantor tanpa memberi tahu rekannya sesame wartawan Istana. Karena konsekuensi yang harus ditanggung jelas sangat berat. Sehingga karena keadaan memaksa semua wartawan untuk saling berbagi maka meskipun berbagi transkrip sebenarnya bertentangan dengan kaidah yang dikeluarkan (Dewan Pers), yang dalam praktiknya setiap hari dilakukan semua wartawan.

Aturan nomor 2 KEJ berbunyi, "Wartawan Indonesia menempuh cara-cara yang profesional dalam melaksanakan tugas jurnalistik.” Konteks di sini adalah, setiap wartawan yang ingin melakukan wawancara dengan narasumber harus ikut hadir atau bertatap muka. Bisa juga dengan menelepon langsung sang narasumber. Adapun praktik titip pertanyaan dianggap tidak memenuhi kaidah KEJ.

Pakar hukum pers Nurdyantoro (2017), menilai, bertukar bahan berita di antara wartawan sebenarnya tidak diperbolehkan. Alasannya, karena wartawan yang bersangkutan tidak langsung mewawancarai narasumber yang dimaksud. Apabila narasumber merasa dirugikan, ia dapat mengajukan keberatan dan tuntutan, bahkan mempermasalahkan secara hokum, karena merasa tidak diwawancarai langsung.

Dalam penelitian berjudul "Pemahaman Wartawan Terhadap Etika Profesi" yang dilakukan Eviera Paramita Sandi (2013), praktik kloning berita biasanya sudah terkoodinasi oleh 
para wartawan di pos-pos tertentu dan karenanya sifat berita lokal seperti piala bergilir. Eviera menyebutkan, biasanya yang melakukan praktik seperti itu adalah wartawan media daring, yang biasanya bertugas seorang diri.

Padahal, di sisi lain, mendapatkan beban dari kantor cukup banyak, mulai wawancara dengan narasumber, mengambil foto, bahkan merekam suara dan video sekaligus untuk melengkapi berita. Di sini antara tanggung jawab dan pekerjaan yang dilakukan wartawan memang terkesan tidak seimbang.

Kondisi itu pula yang disampaikan informan wartawan Istana, yang dalam kondisi tertentu memang harus terpaksa untuk berbagi tugas. Misalnya, usai rapat kabinet atau pelantikan pejabat tinggi negara, yang pasti dihadiri presiden, wakil presiden, dan seluruh menteri, membuat wartawan Istana saling berkomunikasi untuk mengatur strategi supaya semua wawancara dengan pejabat terkait bisa terkover.

Karena wartawan Istana biasanya lebih mengutamakan pesanan kantor yang harus dikerjakan, mereka akan mencegat pejabat terkait. Adapun pejabat lain bisa langsung masuk mobil dan pergi, yang itu tentu saja sangat dihindari oleh para wartawan Istana. Alhasil, mereka saling bersepakat satu sama lain untuk menjaga supaya semua pejabat yang hadir dapat dimintai komentar terkait isu atau masalah yang menyedot perhatian masyarakat.

Karena kalau komunikasi untuk menjalin kerja sama tidak dilakukan, bisa saja hanya ada segelintir wartawan yang mendapatkan berita, sementara wartawan lainnya merasa kecolongan. Apabila ternyata berita itu mempunyai nilai berita yang sangat tinggi maka mereka bisa kelabakan, karena dianggap kantor tidak menguasai pos tersebut, lantaran tidak menulis berita yang didapat wartawan lain.

Demi menghindari hal seperti itu, akhirnya mereka berkompromi dan sepakat untuk saling menjaga satu sama lain. Dengan begitu, menurut informan, tidak ada satu pun wartawan Istana yang mencoba membuat berita eksklusif. Dalam kasus berita yang naik di media daring, biasanya yang terjadi adalah ada wartawan yang naik duluan karena menulis lebih cepat dibandingkan wartawan media lain. Kejadian seperti itu dianggap biasa dan lumrah, karena semua wartawan Istana tetap mendapatkan berita.

"Kalau mau aman semua, ya saling mengamankan," begitu penjelasan salah satu informan. Dia menjelaskan, konteks itu bukan berarti melanggar Kode Etik Jurnalistik (KEJ) yang dikeluarkan oleh Dewan Pers. Etika jurnalistik adalah standar aturan perilaku dan moral, yang mengikat para jurnalis dalam melaksanakan pekerjaannya.

Meski begitu, praktik berbagi transkrip memang membuat ada wartawan yang tidak melakukan wawancara secara langsung, namun langkah itu tetap dilakukan lantaran terdesak keadaan. Bertukar berita di antara wartawan yang kemudian sedikit diedit sebelum dikirim ke media masing-masing marak terjadi. Praktik ini sangat sering dilakukan oleh wartawan media daring yang bertugas di lapangan, terutama yang "ngepos" di tempat-tempat tertentu. Sehingga telah menjadi bagian dari cara kerja mereka dan dianggap wajar (Garini and Besman 2018).

Konteks keadaan di sini, bisa saja seorang wartawan sedang dalam perjalanan. Namun, karena terjebak macet atau alasan lainnya, dia dating terlambat. Otomatis wartawan Istana tersebut lebih memilih mengantisipasinya dengan mengontak di grup rekannya yang sudah tiba di lokasi untuk mengamankan wawancara dengan pejabat terkait. Karena jika hal itu tidak dilakukan, ia bakal kena masalah dengan kantor karena luput memberitakan sebuah berita yang menarik.

Demi menjaga keamanan dan agar berita yang ditulis tidak sampai bermasalah, kadang wartawan Istana melakukan verifikasi ulang. Caranya adalah wartawan yang tidak ikut 
wawancara langsung meminta kepada rekannya untuk berbagi rekaman. Hal itu dilakukan jika ada wartawan yang ragu dengan hasil transkipan yang diterima.

Dengan cara mendengarkan rekaman secara langsung, verifikasi secara ketat sedang dilakukan supaya menghindarkan si wartawan Istana dari melakukan sebuah kesalahan dalam membuat berita. Sehingga sampai detik ini, informan selama bertugas di Istana Kepresidenan belum pernah mendapatkan komplain atau pengaduan dari narasumber terkait berita yang dibuat, meski ada di antara media yang tidak ikut wawancara langsung, namun membuat berita berdasarkan hasil kiriman transkrip rekan-rekannya sesama wartawan Istana.

\section{KESIMPULAN}

Hasil penelitian ini menunjukkan wartawan Istana dalam membuat berita memang terkesan seragam satu dan lainnya, meskipun mereka berasal dari media yang berbeda. Hal itu lantaran narasumber yang dijadikan bahan berita merupakan orang yang sama, yang biasanya diwawancara secara ramai-ramai atau berbarengan.

Kemudahan teknologi membuat wartawan bisa saling berbagi hasil wawancara maupun transkrip. Hasil wawancara bisa langsung dibagikan di grup sehingga semua yang tidak ikut wawancara pun bisa membuat berita.

Dalam membuat berita, wartawan Istana memiliki kesepakatan tidak tertulis untuk tak ada wartawan yang membuat berita eksklusif demi kebaikan bersama. Karena kalau ada satu wartawan yang mencoba membuat berita dengan niatan membuat bobol wartawan lainnya, maka orang tersebut akan dijauhi rekan lainnya. Wartawan Istana dalam membuat berita sangat terbuka untuk berbagi dengan rekannya dari media lain.

Rasa saling membantu itu dilakukan, karena bisa saja sekarang yang membagikan transkrip suatu saat meminta pertolongan ke wartawan yang dulu membantunya. Praktik saling berkomunikasi satu sama lain membuat berita yang dihasilkan wartawan Istana terkesan seragam, meski tentu saja angle berita dibuat berbeda antarmedia. Karena itu, tidak mengherankan jika pemberitaan, khususnya di media daring terkesan seragam karena memang ada kalanya bahan hasil wawancara dibagikan ke grup wartawan Istana.

\section{DAFTAR PUSTAKA}

Ali, Ahmad Fikri. 2016. "Pola Komunikasi Wartawan Radio Dalam Mencari Berita." Jurnal Ilmu Sosial Dan Ilmu Politik 5 (1): 28.

Dewan Pers. n.d. "Dewan Pers Kode Etik.Pdf."

Easa, Khalid M. 2020. "Marshall McLuhan's Understanding Media: The Extensions of Man ( An Analysis of How the Medium Is the Message Challenges Conventional Thought About Mans Relationships with Technology ...," no. March.

Garini, Tsana, and Abie Besman. 2018. "Praktik Jurnalisme Kloning Di Kalangan Wartawan Online." Mediator: Jurnal Komunikasi 11 (1): 1-9. https://doi.org/10.29313/ mediator.v11i1.2736.

Griffin. 2011. A First Look at Communication Theory. New York: McGraw-Hill.

Gunawan, Iman. 2013. “KUALITATIF Imam Gunawan.” Pendidikan, 143. http://fip.um.ac.id /wp-content/uploads/2015/12/3_Metpen-Kualitatif.pdf.

Hidayat, Dasrun, and Anisti Anisti. 2015. "Wartawan Media Now Dalam Mengemas Berita: 
Perspektif Situational Theory." Jurnal ASPIKOM 2 (5): 295. https://doi.org/10.24329/aspikom.v2i5.81.

Juditha, Christiany. 2016. "Jurnalisme Damai Dalam Konflik Agama Di Tolikara Di Tempo.Co.” Jurnal Penelitian Komunikasi Dan Opini Publik 20 (1): 18.

Lawasi, Eva Silvani, and Boge Triatmanto. 2017. "Pengaruh Komunikasi, Motivasi, Dan Kerjasama Tim Terhadap Peningkatan Kinerja Karyawan." Jurnal Manajemen Dan Kewirausahaan 5 (1). https://doi.org/10.26905/jmdk.v5i1.1313.

Nurdyantoro, A D. 2017. "Pergeseran Etika Jurnalistik Dalam Pers Industri." Jurnal Pembangunan Dan Kebijakan Publik .... https://core.ac.uk/download/pdf/249324635.pdf.

Oktavianti, Roswita. 2018. "Reportase Dalam Hegemoni Pemerintah Dan Media: Studi Kasus Jurnalis Kepresidenan Era Soeharto Dan Joko Widodo." Jurnal Komunikasi Indonesia 5 (1): 37-47. https://doi.org/10.7454/jki.v5i1.8331.

Rahmat, Pupu Saeful. 2009. "Ragam Penelitian Kualitatif.” https://doi.org/10.31227/osf.io /wtncz.

Sandi, Eviera Paramita. 2013. "Pemahaman Wartawan Terhadap Etika Profesi." Skripsi Universitas Brawijaya.

Sari, Fitri Meliya. 2014. “Analisis Penerapan Kode Etik Jurnalistik Pada Harian Serambi Indonesia.” INTERAKSI: Jurnal Ilmu Komunikasi 3 (2): 131-39. https://doi.org /10.14710/interaksi,3,2,131-139.

Sari, Shinta Nofita, and M Rinaldo Marajari. 2016. "Efektivitas Komunikasi Interpersonal Universitas Sari Mutiara Indonesia.” Lensa Mutiara Komunikasi, 36-48.

Simamora, Nurhawati, Mega Ulva, and Sari Sihombing. 2017. "Peranan Komunikasi Antar Pribadi Dalam Kepuasan Berikteraksi Di Kalangan Mahasiswa Fakulitas Ekonomi Dan Ilmu Sosial USM- INDONESIA Program Studi Ilmu Komunikasi Universitas Sari Mutiara Indonesia." Jurnal Lensa Mutiara Komunikasi Vol 1: 55-66.

Sugiyono, P D. 2017. "Metode Penelitian Bisnis: Pendekatan Kuantitatif, Kualitatif, Kombinasi, Dan R\&D." Penerbit CV. Alfabeta: Bandung.

Syah, S. 2011. Rambu-Rambu Jurnalistik: Dari Undang-Undang Hingga Hati Nurani. Pustaka Pelajar. https://books.google.co.id/books?id=xilRygAACAAJ.

Wibawa, Darajat. 2012. "Meraih Profesionalisme Wartawan." MIMBAR, Jurnal Sosial Dan Pembangunan 28 (1): 113. https://doi.org/10.29313/mimbar.v28i1.345.

Widodo, Yohanes. 2017. "Menyoal Etika Jurnalisme Kontemporer: Belajar Dari OhmyNews." Jurnal ASPIKOM 1 (1): 41. https://doi.org/10.24329/aspikom.v1i1.7. 